\title{
Development of High Welding speed in Friction Stir Welded 5182-H111, and the Resulting Influence on Down Force
}

\author{
D Bernard ${ }^{\mathrm{a}^{*}}$, D G Hattingh ${ }^{\mathrm{b}}$ \\ Department of Mechanical Engineering, Nelson Mandela Metropolitan University, Port Elizabeth, \\ South Africa \\ adreyer.bernard@nmmu.ac.za, ${ }^{b}$ danie.hattingh@nmmu.ac.za
}

Keywords: Friction stir welding, FSW, down force, weld pitch, 'Lazy S'

\begin{abstract}
In this manuscript the development of the process parameters to friction stir weld $5.15 \mathrm{~mm}$ thick AA5182-H111 at a feed rate of $1500 \mathrm{~mm} / \mathrm{min}$ is discussed. Compared to a weld made at $200 \mathrm{~mm} / \mathrm{min}$ the weld-pitch had to be reduced from $2.0 \mathrm{rev} / \mathrm{mm}$ to $0.3 \mathrm{rev} / \mathrm{mm}$ and down force increased from $27 \mathrm{kN}$ to $59 \mathrm{kN}$ to create a weld with tensile-and yield strength exceeding that of the parent material, whilst elongation was only marginally reduced. The low weld pitch coupled with the high feed rate resulted in a reduction in the weld temperature and an increase in the process reaction forces. A lower down force was sufficient to consolidate the stir zone and result in ultimate tensile strength yield strength exceeding that of the parent material. However, elongation was reduced since the low weld pitch also reduced the effectiveness of the flutes on the pin to break up and disperse the oxide layer, rendering a pseudo bond along the 'Lazy S'. This pseudo bond was eliminated through an increase in the down force.
\end{abstract}

\section{Introduction}

Over the past two decades friction stir welding has been developed to the point where it can successfully be applied in the production industry [1]; however, friction stir welding of 5xxx aluminium alloys tends to be carried out at weld speeds below $500 \mathrm{~mm} / \mathrm{min}$ [2], While feed rates of up $6000 \mathrm{~mm} / \mathrm{min}$ has been reported in $6 \mathrm{xxx}$ series aluminium alloys with a plate thickness of $4 \mathrm{~mm}$ (scaled from macrograph) [3]. Although joints made in aluminium through FSW generally have superior properties over fusion welding methods, the low welding speeds accompanied by the increased preparation time means that FS welding mainly applied in critical, high value, low production volume components. Rao et al. [4] welded 3mm thick cold rolled AA5083 with a feed rate and spindle rotational speed of $1000 \mathrm{~mm} / \mathrm{min}$ and $1800 \mathrm{rpm}$ respectively. They removed microtensile samples longitudinally to the weld direction, and their results indicated an average longitudinal yield strength in the stir zone of $160 \mathrm{MPa}$. Deplus et al. [5] reported on the residual stresses in friction stir welded joints of $4 \mathrm{~mm}$ thick AA5754-H111 made with a spindle speed of $1000 \mathrm{rev} / \mathrm{min}$ and a feed rate of $1100 \mathrm{~mm} / \mathrm{min}$. They did, however, not report on the macrostructure or tensile properties of the joints. Up to date no other work has been found where $5 \mathrm{~mm}$ thick $5 \mathrm{xxx}$ series aluminium alloy have been welded above $1100 \mathrm{~mm} / \mathrm{min}$.

Conventionally, weld pitch (spindle speed / feed rate) is above 1rev/mm. Lakshminarayanan et al. [6] investigated a process window with spindle speed and feed rate ranging from 500rpm to $1500 \mathrm{rpm}$, and $30 \mathrm{~mm} / \mathrm{min}$ to $150 \mathrm{~mm} / \mathrm{min}$ respectively (weld pitch between $3.33 \mathrm{rev} / \mathrm{mm}$ and $36.7 \mathrm{rev} / \mathrm{mm}$ ). They concluded that the spindle speed should be sufficiently high such that the material moves around the pin fast enough to fill the cavity behind the tool. In AA2219, weld quality was dependent on both weld pitch and specific energy input, since this is heat treatable alloy. They stated that hot processing with sticking conditions will result in excessive material flow leading to (amongst others) nugget collapse, while cold processing with slip conditions will result in insufficient material flow causing wormholes or lack of consolidation. Some studies have, however, shown that it is possible to carry out a friction stir weld with a pitch below $1 \mathrm{rev} / \mathrm{mm}$; the parameters 
reported by Deplus [5], as stated earlier, equated to a weld-pitch of $0.91 \mathrm{rev} / \mathrm{mm}$. Commin et al. [7] found that at a weld speed of $2000 \mathrm{~mm} / \mathrm{min}$, and a rotational speed of $600 \mathrm{rpm}(0.3 \mathrm{rev} / \mathrm{mm})$ was sufficient to create a weld with similar properties to weld made with weld pitch above $2 \mathrm{rev} / \mathrm{mm}$ in $2 \mathrm{~mm}$ thick strain hardening AZ31-O magnesium alloy. Similar weld pitch have been reported in FSW of $1.6 \mathrm{~mm}$ thick stainless steel by Ishikawa et al. [8]. They achieved tensile failure in the parent material with welds made at $1200 \mathrm{~mm} / \mathrm{min}$ and $600 \mathrm{rpm}$, relating to a weld-pitch of $0.5 \mathrm{rev} / \mathrm{mm}$. These last two examples are, however, in plates with a thickness below $2 \mathrm{~mm}$. In the current paper, the process parameter development is presented were a conventional tool that was developed for weld speeds of $200 \mathrm{~mm} / \mathrm{min}$ was used to reach a weld speed of $1500 \mathrm{~mm} / \mathrm{min}$, in $5.15 \mathrm{~mm}$ thick AA5182-H111 plate.

\section{Experimental set-up}

Material. This study was performed on aluminium alloy 5182-H111 (T500) with a thickness of $5.15 \mathrm{~mm}$ which is used to manufacturing of road tankers, of which the chemical composition is shown in Table 1.

Table 1. Chemical composition (in wt. \%) of AA5182-H111 (T500).

\begin{tabular}{|c|c|c|c|c|c|c|c|}
\hline $\mathrm{Si}$ & $\mathrm{Fe}$ & $\mathrm{Cu}$ & $\mathrm{Mn}$ & $\mathrm{Mg}$ & $\mathrm{Cr}$ & $\mathrm{Ti}$ & $\mathrm{Al}$ \\
\hline 0.103 & 0.223 & 0.089 & 0.456 & 4.89 & 0.039 & 0.008 & 94.2 \\
\hline
\end{tabular}

Weld preparation. The friction stir weld coupons was made on a 4-axis MTS friction stir welding platform at the Nelson Mandela Metropolitan University. The welding tool had a shoulder diameter of $22 \mathrm{~mm}$, and a threaded conical pin, with a major diameter of $10 \mathrm{~mm}$ and a minor diameter of $8 \mathrm{~mm}$. The pin also contained 3 equally spaced flutes, as illustrated in Fig. 1. The temperature in the pin was measured during welding by means of a K-type thermocouple imbedded inside it, roughly $0.5 \mathrm{~mm}$ from the side-wall and at mid weld depth.

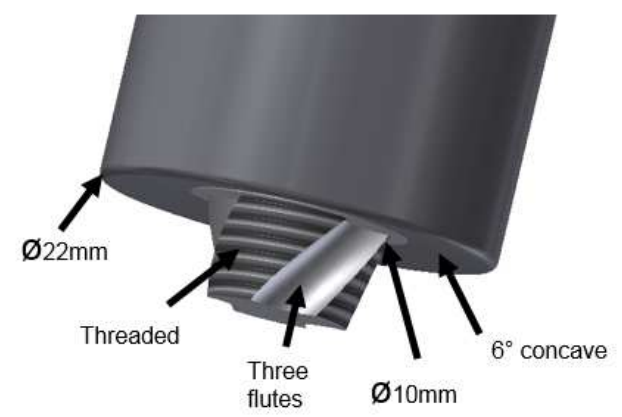

Fig. 1. Friction stir welding tool features

Methodology. It was investigated whether a FS weld could be made at $1500 \mathrm{~mm} / \mathrm{min}$ with a tool which was initially developed for a feed rate of $200 \mathrm{~mm} / \mathrm{min}$, accompanied by a spindle speed of $500 \mathrm{rpm}$ and a down force of $27 \mathrm{kN}$ (This weld will be referred to as the "slow weld", and will be presented as "W10" in this manuscript). Process development to achieve the "fast weld" was approached in three stages; Stage I and $I I$ was performed by making bead on plate welds of $200 \mathrm{~mm}$ in length, and the down force on the tool was controlled at $39 \mathrm{kN}$ throughout both stages. Since there was no clear indication which parameters would be necessary to create a high speed weld, the process parameters for Stage I (W1 - W2) was selected by first adopting a conventional weld pitch (spindle speed / feed rate $[\mathrm{rev} / \mathrm{mm}]$ ) greater than one. Hereafter spindle speed was reduced for the same feed rates, $(W 3-W 4$ ), resulting in a minimum weld pitch of $0.7 \mathrm{rev} / \mathrm{mm}$. In Stage II the most promising weld from Stage I was selected, and the feed rate was increased to $1500 \mathrm{~mm} / \mathrm{min}$ while keeping the spindle speed constant (W5). Hereafter the spindle speed was further reduced (W6 W7). In Stage III the parameters from "W7" was transferred to butt welds $(W 8-W 9)$ and only the 
down force on the tool was increased. The force was initially increased to eliminate voids, after which it was increased based on the performance of a longitudinal (all-weld) tensile samples.

\section{Results}

A summary of the process parameters that was investigated during this study is presented in Table 2. Macro and micrographs from Stage $I$ is shown in Figs. 2 and 3 respectively. In both these figures, (a) and (b) presents two welds which was made with a spindle speed of $1500 \mathrm{rev} / \mathrm{min}$, and a feed rate of $700 \mathrm{~mm} / \mathrm{min}$ and $1000 \mathrm{~mm} / \mathrm{min}$ respectively. For both welds the stir zone was broader at the bottom than at the top, as seen in Fig. 2, which is indicative of high downward material flow. However, as seen from Fig. 3, neither stir zones was sufficiently plasticized. Leitão et al. [9] presented similar stir zone structures from welds made at $1000 \mathrm{rpm}$ and $200 \mathrm{~mm} / \mathrm{min}$. They found that a reduction in tool rotation at a constant feed rate resulted in better material flow. The subsequent two welds was made at 700 rpm, again with feed rates of $700 \mathrm{~mm} / \mathrm{min}$ (weld pitch $=1$ $\mathrm{rev} / \mathrm{mm}$ ) and $1000 \mathrm{~mm} / \mathrm{min}$ (weld pitch $=0.7 \mathrm{rev} / \mathrm{mm}$ ), and are presented in Figs. 2 and 3 as (c) and (d) respectively. The stir zones of the welds with the reduced weld pitch had a different shape to the high pitch welds, having a similar diameter at the top and at the bottom of the weld. With a high weld pitch a higher volume of material is forced downward, resulting in a wider base. The stir zone of both these welds were completely plasticized, and no voids were visible in either welds. The weld pitch of $0.7 \mathrm{rev} / \mathrm{mm}$ and $1.0 \mathrm{rev} / \mathrm{mm}$ for welds "W3" and "W4" is similar to that reported by Deplus et al. [4].

Table 2. Process Parameters investigated during this study.

\begin{tabular}{|c|c|c|c|c|c|c|c|}
\hline Stage & Weld \# & $\begin{array}{l}\text { Down } \\
\text { force } \\
{[\mathrm{kN}]}\end{array}$ & $\begin{array}{l}\text { Feed rate } \\
{[\mathrm{mm} / \mathrm{min}]}\end{array}$ & $\begin{array}{c}\text { Spindle } \\
\text { Speed } \\
{[\mathrm{rev} / \mathrm{min}]}\end{array}$ & $\begin{array}{c}\text { Weld } \\
\text { pitch } \\
{[\mathrm{rev} / \mathrm{mm}]}\end{array}$ & $\begin{array}{l}\text { Pin } \\
\text { Temp. } \\
{\left[{ }^{\circ} \mathrm{C}\right]}\end{array}$ & Comments \\
\hline \multirow{4}{*}{$\begin{array}{c}\text { Stage I } \\
\text { (Bead on Plate) }\end{array}$} & W1 & 39 & 700 & 1500 & 2.14 & 574 & Insufficient Plasticization \\
\hline & W2 & 39 & 1000 & 1500 & 1.50 & 566 & Insufficient Plasticization \\
\hline & W3 & 39 & 700 & 700 & 1.00 & 548 & Complete consolidation \\
\hline & W4 & 39 & 1000 & 700 & 0.70 & 536 & Complete consolidation \\
\hline \multirow{3}{*}{$\begin{array}{c}\text { Stage II } \\
\text { (Bead on Pate) }\end{array}$} & W5 & 39 & 1500 & 700 & 0.47 & - & $\begin{array}{l}\text { Evidence of plasticization, } \\
\text { Incomplete consolidation }\end{array}$ \\
\hline & W6 & 39 & 1500 & 600 & 0.40 & - & $\begin{array}{l}\text { Good consolidation, Void } \\
\quad(483 \mu \mathrm{m} \times 370 \mu \mathrm{m})\end{array}$ \\
\hline & W7 & 39 & 1500 & 500 & 0.30 & - & $\begin{array}{c}\text { Good consolidation, Void } \\
(438 \mu \mathrm{m} \times 21 \mu \mathrm{m}) \& \\
(63 \mu \mathrm{m} \times 79 \mu \mathrm{m})\end{array}$ \\
\hline \multirow{2}{*}{$\begin{array}{c}\text { Stage III } \\
\text { (Butt-Weld) }\end{array}$} & W8 & 52 & 1500 & 500 & 0.30 & - & $\begin{array}{l}\text { Complete consolidation, Void } \\
\qquad(28 \mu \mathrm{m} \times 57 \mu \mathrm{m})\end{array}$ \\
\hline & W9 & 59 & 1500 & 500 & 0.30 & 505 & Complete consolidation \\
\hline $\begin{array}{l}\text { "Slow Weld" } \\
\text { (Butt-Weld) }\end{array}$ & W10 & 27 & 200 & 500 & 2.50 & 543 & Complete consolidation \\
\hline
\end{tabular}




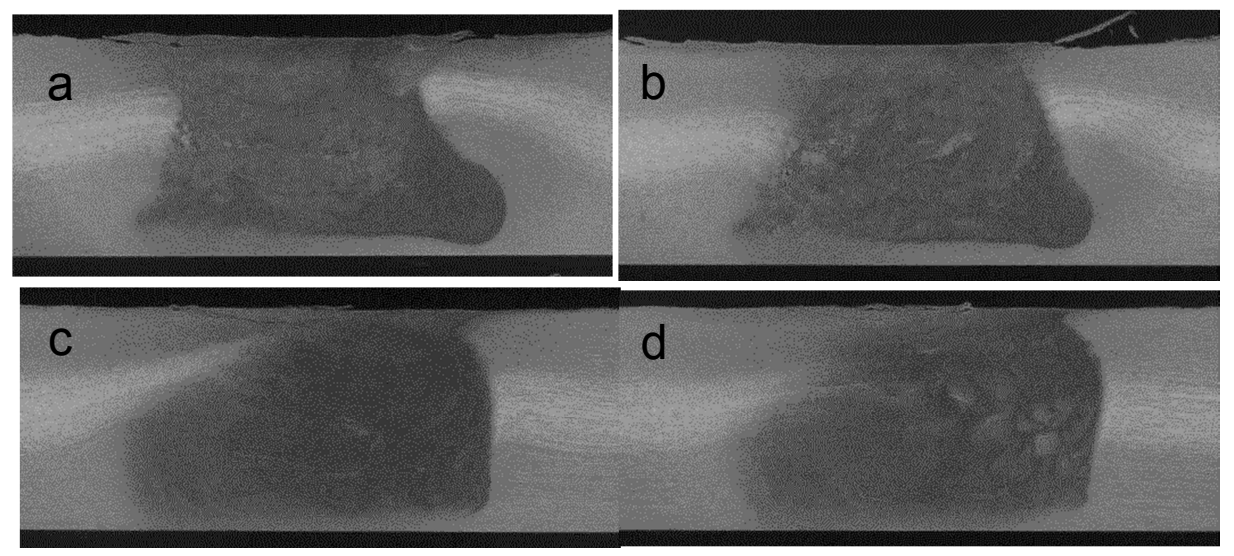

Fig. 2. Macrographs of the stir zone of (a) "W1", (b) "W2", (c) "W3" and (d) "W4".
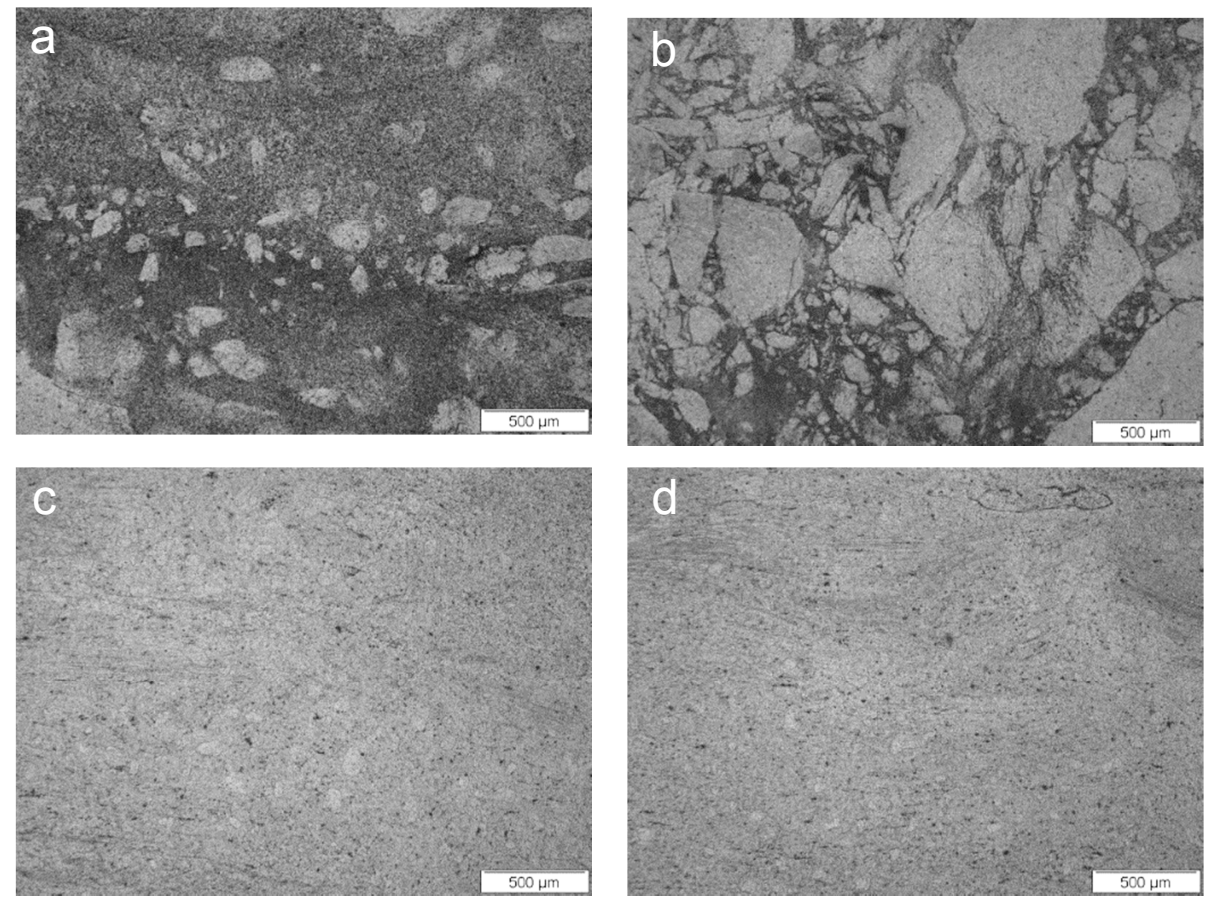

Fig. 3. Micrographs of the stir zone of (a) "W1", (b) "W2", (c) "W3" and (d) "W4".

Stage II was initiated with by increasing the weld speed for "W5" to $1500 \mathrm{~mm} / \mathrm{min}$ while maintaining a spindle speed of $700 \mathrm{rev} / \mathrm{min}$ and a down force on the tool at $39 \mathrm{kN}$. The appearance of the stir zone for "W5" is shown in Fig. 4 (a). Although the stir zone was not completely consolidated, there was sufficient evidence of plasticization with an increased feed rate and decreased weld pitch. For welds "W6" and "W7", of which the micrographs are shown in Fig. 4 (b) and (c), the rotational speed was reduced to $600 \mathrm{rev} / \mathrm{min}$ and $500 \mathrm{rev} / \mathrm{min}$ respectively, while the feed rate and down force remained at $1500 \mathrm{~mm} / \mathrm{min}$ and $39 \mathrm{kN}$. Reducing the spindle speed to $500 \mathrm{rev} / \mathrm{min}$ improved plasticisation and consolidation, and reduced the void significantly.

During Stage III the parameters was transferred to butt welds. The void was reduced to a size of $28 \mu \mathrm{m} \times 57 \mu \mathrm{m}$ in "W8", as indicated by the white arrow in Fig. 5, by increasing the down force to $52 \mathrm{kN}$. A longitudinal (all-weld) tensile sample from "W8" reached an ultimate tensile strength (UTS) of $314.0 \mathrm{MPa}$ and an elongation of $21.6 \%$. The fracture surface, however, displayed evidence of a forging defect, or pseudo bond. The forging defect was eliminated by increasing the down force to $59 \mathrm{kN}$ for weld "W9". Fig. 6 presents the tensile curves for "W8", "W9" and the parent material (perpendicular to the rolling direction), while Table 3 presents a summary of the results. 

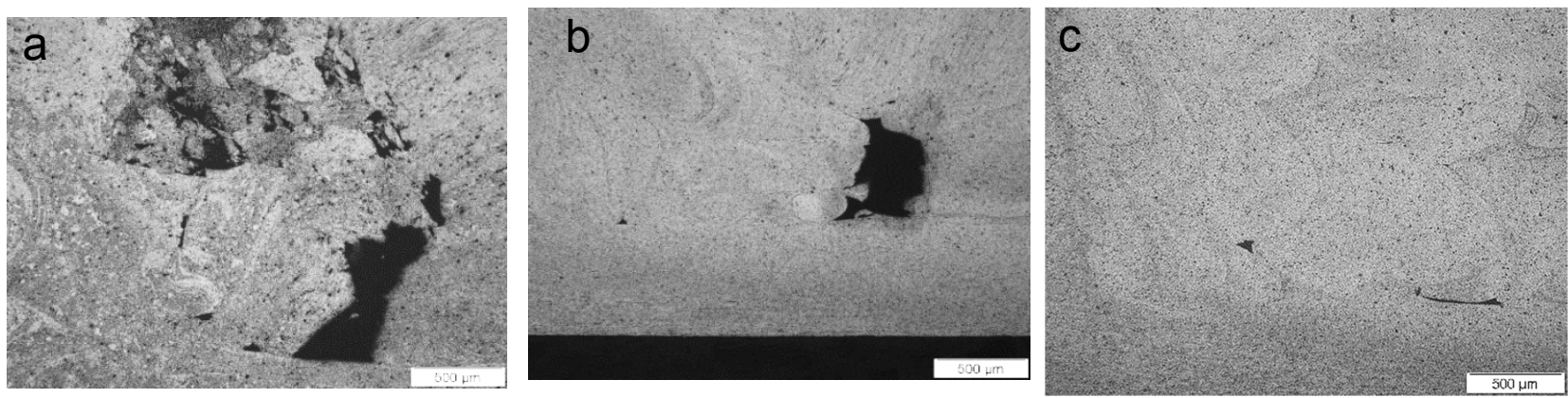

Fig. 4. Micrographs showing the influence of reducing the spindle speed at a constant feed rate and down force of $1500 \mathrm{~mm} / \mathrm{min}$ and $39 \mathrm{kN}$ respectively (a) "W5" [700 rev/min] (b) "W6" [600 rev/min], and (b) "W7" [500rev/min].

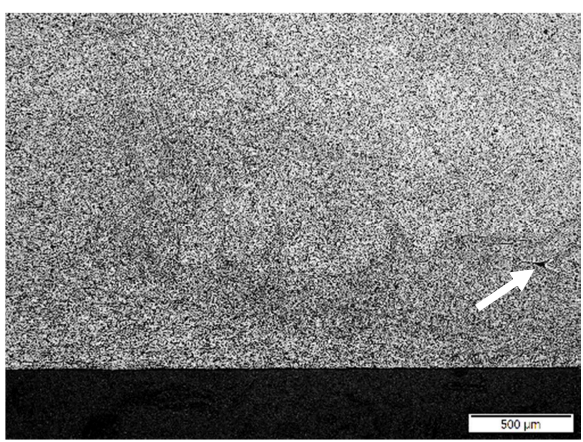

Fig. 5. Micrograph of weld "W8" made at $1500 \mathrm{~mm} / \mathrm{min}, 500 \mathrm{rev} / \mathrm{min}$ and $52 \mathrm{kN}$.

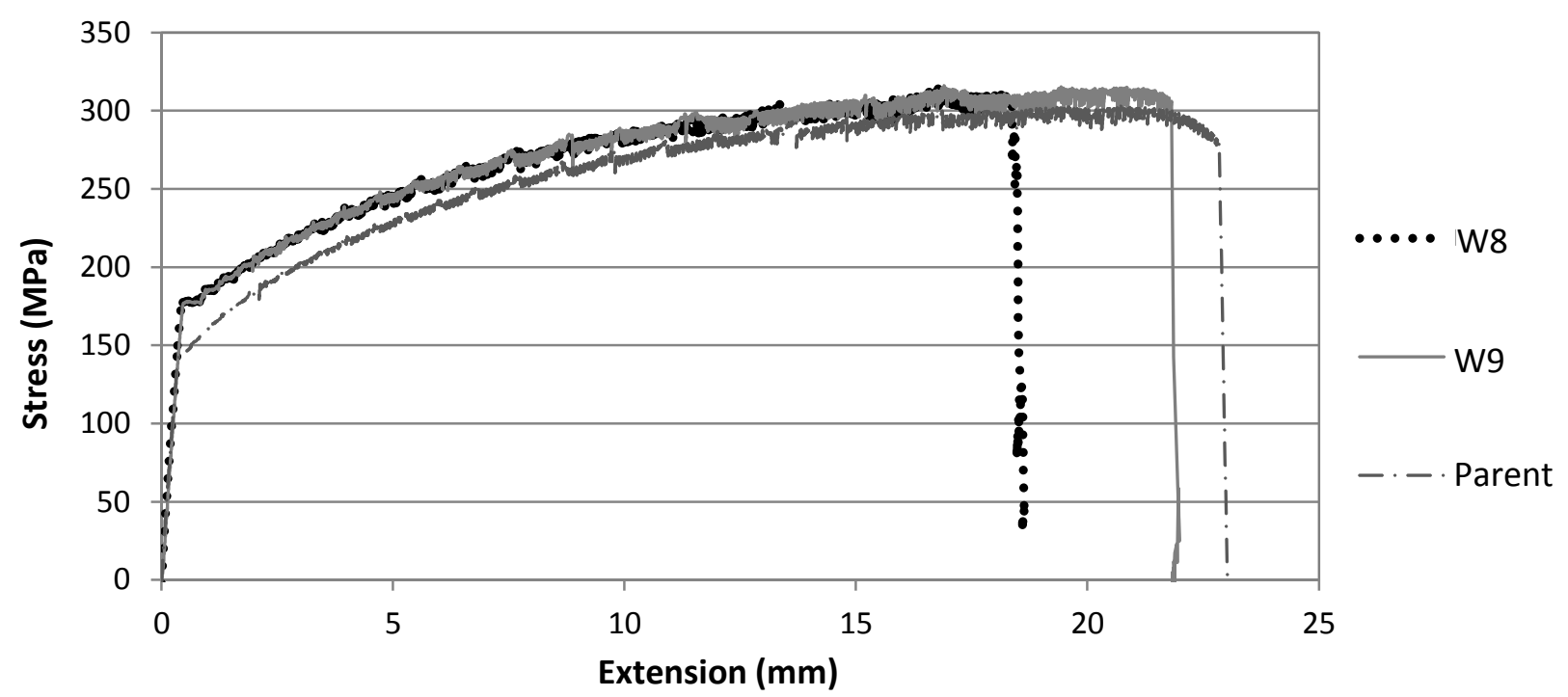

Fig. 6. Tensile flow curves for the parent material and welds "W8" [52kN] and "W9" [59kN].

No change in UTS or yield strength was observed with an increase in the down force, however elongation increased from $21.6 \%$ to $25.4 \%$ since the forging defect was eliminated. The UTS and yield strength for "W9" was $4.6 \%$ and $22.5 \%$ higher than the parent material respectively. The fracture surfaces of "W8" and "W9" is shown in Fig. 7 (a) and (b). The forging defect in "W8" is indicated by red arrows, while "W9" displayed no indication of a forging defect. With a weld pitch of $0.3 \mathrm{rev} / \mathrm{mm}$ the tool completes one rotation every $3 \mathrm{~mm}$ which seems to reduce the effectiveness of the flutes in breaking up and dispersing the oxide layer. These continuous oxide bands therefore creates a boundary within the plasticized material which resists forging, creating a weak or "pseudo bond" $[10,11]$. It is believed that the increased down force allowed this boundary to be overcome, allowing the material to be forged. The yield strength of $177.7 \mathrm{MPa}$ is marginally higher than the 
average yield strength of the stir zone in the work by Rao et al. [4] of $160 \mathrm{MPa}$, which was made in a cold rolled AA5083 (AA5083 has a similar chemical composition to AA5182).

Table 3. Tensile properties of the parent material and welds "W8" [52kN] and "W9" [59kN]

\begin{tabular}{|c|c|c|c|c|}
\hline Weld \# & $\begin{array}{c}\text { Down } \\
\text { force } \\
{[\mathrm{kN}]}\end{array}$ & $\begin{array}{c}\text { UTS } \\
{[\mathrm{MPa}]}\end{array}$ & $\begin{array}{c}\text { Yield } \\
\text { Strength } \\
{[\mathrm{MPa}]}\end{array}$ & $\begin{array}{c}\text { Elong- } \\
\text { gation } \\
{[\%]}\end{array}$ \\
\hline W8 & 52 & 314.0 & 177.9 & 21.6 \\
\hline W9 & 59 & 316.0 & 177.7 & 25.4 \\
\hline Parent & - & 302.2 & 145.1 & 27.8 \\
\hline
\end{tabular}

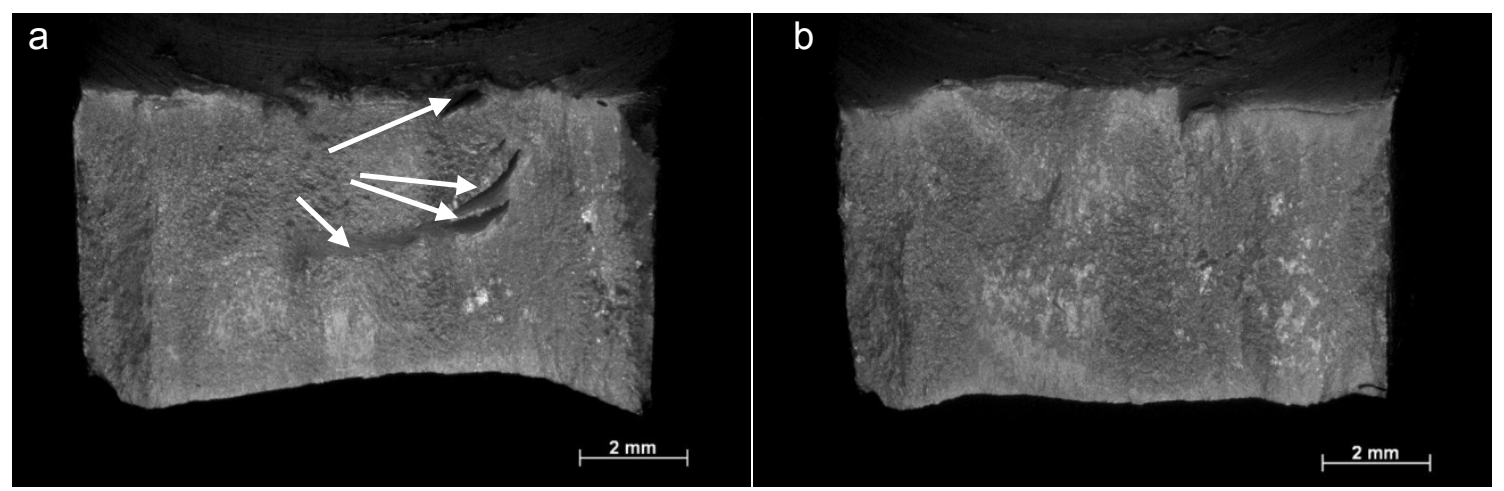

Fig. 7. Fracture surface appearance of tensile samples for welds made at $500 \mathrm{rev} / \mathrm{min}$ and $1500 \mathrm{~mm} / \mathrm{min}$, with a down force of (a) "W8" [52kN] and (b) "W9" [59kN].
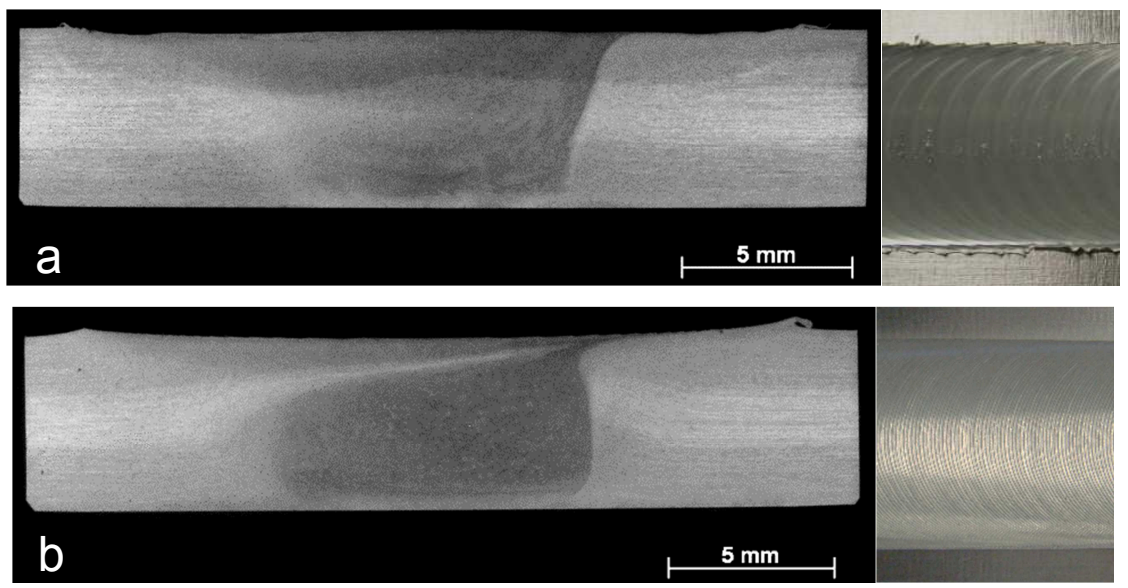

Fig. 8. Macrograph and surface appearance of the fast and slow welds, both made with a spindle speed of 500 rev/min (a) "W9" [1500mm/min] (b) "W10" [200 $\mathrm{mm} / \mathrm{min}]$.

Fig. 8 presents the macrographs and surface appearance for the $1500 \mathrm{~mm} / \mathrm{min}$ weld ("W9") and $200 \mathrm{~mm} / \mathrm{min}$ weld ("W10"). Both these weds were made at a spindle speed of 500rpm, however the down force was increased from $27 \mathrm{kN}$ for a feed rate of $200 \mathrm{~mm} / \mathrm{min}$ ("W 10 "), to $59 \mathrm{kN}$ to achieve adequate properties for a feed rate of $1500 \mathrm{~mm} / \mathrm{min}$ ("W9"). Irrespective of these vast differences in weld speed and down force, both welds had a fully consolidated stir zone and good surface appearance. It is well documented that a decrease in feed for a constant spindle speed reduces the peak temperature [12], and since both the fast and slow welds were made at $500 \mathrm{rev} / \mathrm{min}$, the pin temperature was reduced from $543^{\circ} \mathrm{C}$ ("W10"; weld pitch $=2.5 \mathrm{rev} / \mathrm{mm}$ ) to $505^{\circ} \mathrm{C}$ ("W9"; weld pitch $=0.3 \mathrm{rev} / \mathrm{mm}$ ). The cooler weld coupled with the increased material interaction resulting from the reduced weld pitch also resulted in an increase in down force, drag force and spindle torque. "W1" and "W2", made at high feed rate as well as high weld pitch, resulted in pin temperatures of 
$574^{\circ} \mathrm{C}$ (weld pitch $=2.14 \mathrm{rev} / \mathrm{mm}$ ) and $566^{\circ} \mathrm{C}$ (weld pitch $=1.5 \mathrm{rev} / \mathrm{mm}$ ) respectively; which approaches the melting point of the material. "W3" and "W4", both made with a spindle speed of $700 \mathrm{rev} / \mathrm{min}$ and feed rates of $700 \mathrm{~mm} / \mathrm{min}$ (weld pitch $=1 \mathrm{rev} / \mathrm{mm}$ ) and $1000 \mathrm{~mm} / \mathrm{min}$ (weld pitch $=$ $0.7 \mathrm{rev} / \mathrm{mm}$ ) respectively, resulted in peak temperatures of $549^{\circ} \mathrm{C}$ and $536^{\circ} \mathrm{C}$. The two welds in which the pin temperature exceeded $560^{\circ} \mathrm{C}$ was not adequately plasticized, while all the welds with temperatures below $550^{\circ} \mathrm{C}$ displayed sufficient plasticization.

\section{Conclusions}

In this paper the process development for high feed rates in friction stir welded AA5182-H111 was discussed for a tool that was initially designed for low weld speeds. It was found that, in order to make a fast weld with a UTS and yield strength exceeding that of the parent material, the rotational speed of the tool was the same for a feed rate of $200 \mathrm{~mm} / \mathrm{min}$ as well as for $1500 \mathrm{~mm} / \mathrm{min}$. The following conclusions can be deduced from this study:

The welds made at 1500rev/min ("W1"; 700mm/min and "W2"; $1000 \mathrm{~mm} / \mathrm{min}$ ), which had a weldpitch of $2.14 \mathrm{rev} / \mathrm{mm}$ and $1.5 \mathrm{rev} / \mathrm{mm}$ respectively, did not contain a sufficiently plasticised stir zone; yet, at low feed rates of $200 \mathrm{~mm} / \mathrm{min}$, a weld-pitch of $2.5 \mathrm{rev} / \mathrm{mm}$ is adequate to form a weld. Reducing the weld pitch proved to be advantageous at high welding speeds, with a spindle of $500 \mathrm{rev} / \mathrm{min}$ being sufficient to create a fully consolidated weld at a feed rate of $1500 \mathrm{~mm} / \mathrm{min}$; equating to a weld-pitch of $0.3 \mathrm{rev} / \mathrm{mm}$. The nature of the plasticization in the stir zone may be related to the weld temperature, since the pin temperature in "W1" and "W2" exceeded $560^{\circ} \mathrm{C}$, while those welds where the temperature was below $550^{\circ} \mathrm{C}$ (the lowest temperature measured in this study was $505^{\circ} \mathrm{C}$ ) resulted in an adequately plasticized stir zone.

The all-weld longitudinal tensile sample comprising mostly of the dynamically recrystallized stir zone had a yield strength of $177 \mathrm{MPa}$ compared to $145 \mathrm{MPa}$ of the parent material, while the UTS was slightly increased from $302 \mathrm{MPa}$ to $316 \mathrm{MPa}$. Creating a weld at $1500 \mathrm{~mm} / \mathrm{min}$ was achievable, however, it is associated with a large increase in all process forces. The down force on the tool was increased from $27 \mathrm{kN}(200 \mathrm{~mm} / \mathrm{min})$ to $59 \mathrm{kN}(1500 \mathrm{~mm} / \mathrm{min})$ in order to achieve a weld which displayed no evidence of pseudo bonds on the fracture surface of a longitudinal tensile sample, thereby achieving the maximum elongation. While a lower down force $(52 \mathrm{kN})$ may be adequate to consolidate the weld and achieve a UTS and yield strength exceeding that of the parent material, the oxide layer results in a "pseudo bond" which reduced elongation from $25.4 \%$ to $21.6 \%$. The oxide layer seems to arise since the low weld pitch reduces the effectiveness of the flutes in dispersing the oxide layer from the original faying surfaces.

\section{Acknowledgements}

This work was supported by funding received by the joint collaboration between the German Academic Exchange Service (DAAD) and the South African National Research Foundation (NRF), the Advanced Metals Initiative (AMI), and the Technology Innovation Agency (TIA). The authors would also like to thank GRW Engineering, who supplied the material for this study.

\section{References}

[1] T. Kawasaki T. Makino K. Masai H. Ohba Y. Ina M. Ezumi, Application of friction stir welding to construction of railway vehicles. JSME International Journal Series A. 47(3) (2004) 502-511.

[2] D. Rodrigues C. Leitao, R. Louro, H. Gouveia, A. Loureiro, High speed friction stir welding of aluminium alloys. Science and Technology of Welding and Joining. 15(8) (2010) 676-681.

[3] J. Defalco, Friction stir welding vs. fusion welding. Energy. 1 (2006) 3. 
[4] K. Deplus A. Simar W. Haver B. Meester, Residual stresses in aluminium alloy friction stir welds. Int. J. Adv. Manuf. Technol. 56(5-8) (2011) 493-504. English.

[5] D. Rao, J. Heerens, G. Alves Pinheiro, J.F. dos Santos, N.Huber. On characterisation of local stress-strain properties in friction stir welded aluminium AA 5083 sheets using micro-tensile specimen testing and instrumented indentation technique. Materials Science and Engineering: A. 527(18-19) (2010) 5018-5025.

[6] A.K. Lakshminarayanan, S. Malarvizhi, V. Balasubramanian. Developing friction stir welding window for AA2219 aluminium alloy. Transactions of Nonferrous Metals Society of China. 21(11) (2011) 2339-2347.

[7] L. Commin, M. Dumont, J.F. Masse, L. Barrallier. Friction stir welding of AZ31 magnesium alloy rolled sheets: Influence of processing parameters. Acta Materialia. 57(2) (2009) 326334.

[8] T. Ishikawa, H. Fujii, K. Genchi, S. Iwaki, S. Matsuoka, K. Nogi. High speed-high quality friction stir welding of austenitic stainless steel. ISIJ international. 49(6) (2009) 897-901.

[9] C. Leitão, R. Louro, D.M. Rodrigues. Using torque sensitivity analysis in accessing Friction Stir Welding/Processing conditions. Journal of Materials Processing Technology. 212(10) (2012) 2051-2057.

[10] A. Oosterkamp, L.D. Oosterkamp, A. Nordeide. Kissing bond phenomena in solid-state welds of aluminum alloys. WELDING JOURNAL-NEW YORK-.83(8) (2004) 225-S.

[11] Y.S. Sato, H. Takauchi, S.H.C. Park, H. Kokawa. Characteristics of the kissing-bond in friction stir welded Al alloy 1050. Materials Science and Engineering: A. 405(1-2) (2005) 333-338.

[12] M. Peel, A. Steuwer, P. Withers, T. Dickerson, Q. Shi, H. Shercliff. Dissimilar friction stir welds in AA5083-AA6082. Part I: process parameter effects on thermal history and weld properties. Metallurgical and Materials Transactions A. 37(7) (2006) 2183-2193. 